ARCHIWA - KanCELARIE - ZBIORY

NR $4(6) / 2013$

Waldemar ChORĄżYCZEWSKI

Uniwersytet Mikotaja Kopernika w Toruniu

\title{
MoŻliWOŚć POWOŁANIA STUDIÓW DOKTORANCKICH W ZAKRESIE ARCHIWISTYKI W KONTEKŚCIE UZNANIA ARCHIWISTYKI ZA SAMODZIELNĄ DYSCYPLINĘ NAUKOWĄ
}

Słowa kluczowe: studia doktoranckie; archiwistyka jako nauka

Ke y w ord s: doctor studies, archive studies

Abstract

Studia doktoranckie zostały włączone do systemu sformalizowanego kształcenia jako studia trzeciego stopnia. W świetle przepisów ministerialnych program studiów doktoranckich w zakresie archiwistyki musiałby obejmować zajęcia z zakresu: archiwistyki, metodologii nauk, dydaktyki szkoły wyższej, społecznej roli uczonego, prowadzenia zajęć dydaktycznych, nazywanych praktyką zawodową. Czy z powyższego wynika, że nie jest potrzebne seminarium doktoranckie? Wręcz przeciwnie, to seminarium wydaje się najlepszym miejscem na przekazywanie wiedzy i umiejętności z zakresu metodologii nauk, a także właściwej postawy uczonego, świadomego swej społecznej roli. Seminarium rozumiane nie jako tylko i wyłącznie kuźnia prac doktorskich, ale też miejsce dyskusji z udziałem mistrza, uczniów i zaproszonych gości-ekspertów, powinno być przedmiotem o kluczowym znaczeniu i największym wymiarze godzinowym. Wątpliwość budzi kwestia, czy archiwiście potrzebne jest przygotowanie do roli nauczyciela akademickiego? Zarówno profil uniwersyteckich studiów doktoranckich, jak i obserwacja ich skuteczności wskazuje na nieformalne seminarium doktoranckie jako lepszą formę kształcenia doktorskiego archiwi- 
stów. Może jednak warto zastanowić się nad krokami, jakie należy podjąć, gdybyśmy uznali za słuszne powołać studia doktoranckie w zakresie archiwistyki? Czy jest szansa i czy warto o to zabiegać, by archiwistyka znalazła się w tym wykazie? Pozwoliłoby to otworzyć studia doktoranckie w zakresie archiwistyki, a także nadawać stopnie naukowe doktora nauk humanistycznych w zakresie archiwistyki, a nie historii, jak dotychczas. Archiwistyka ma wyraźnie określony przedmiot, zakres i metodologię badań. Dostrzec można też osobną wrażliwość archiwalną równouprawniającą wszystkich użytkowników i cele wykorzystania zasobu. Archiwistyka dojrzała do bycia odrębną dyscypliną wiedzy. Tym samym można się spodziewać, że w końcu ktoś tę dojrzałość spożytkuje, przez co stworzone zostaną formalne przesłanki do powołania studiów doktoranckich w zakresie archiwistyki. Ktoś na pewno tę szansę wykorzysta wcześniej czy później.

Artykuł dotyczy dwóch powiązanych ze sobą, choć odrębnych zagadnień. Pierwsze to formalne ramy uzyskania stopnia naukowego doktora w ramach studiów doktoranckich lub $\mathrm{w}$ inny sposób. Zagadnienie to jest niezależne od dyscypliny naukowej. Zagadnienie drugie to warunki, jakie musi spełnić archiwistyka, by mogła zostać uznana za samodzielną dyscyplinę wiedzy. Uznanie to jest konieczne, by można było powoływać studia doktoranckie w zakresie archiwistyki, a także nadawać stopnie naukowe doktora nauk humanistycznych w tymże zakresie.

$\mathrm{Na}$ początek warto zadać sobie pytanie: dla kogo byłyby przeznaczone studia doktoranckie w zakresie archiwistyki? Dla archiwistów zawodowych, czy też również dla osób zainteresowanych tylko archiwami, ich fenomenem, funkcjonowaniem dziedziny archiwalnej. Są to dwie różne grupy odbiorców usług edukacyjnych. Pierwsza chce zapewne łączyć archiwalną działalność zawodową z pracą naukową. Przedstawiciele drugiej będą uprawiać naukę równolegle z działalnością dydaktyczną na poziomie szkoły wyższej - takie założenia odnaleźć można w naszych aktach prawnych, regulujących kwestię studiów doktoranckich. Studia doktoranckie w obecnym kształcie przeznaczone są dla przyszłych nauczycieli akademickich. Nie są one atrakcyjną ofertą dla tych, którzy stopień naukowy doktora traktują dokładnie jako stopień naukowy, czyli potwierdzenie umiejętności badawczych.

Jeśli nie w ramach studiów doktoranckich, to w jaki sposób zawodowo czynny archiwista może uzyskać stopień doktorski? Z absolutnie wolnej stopy, czyli dzięki współpracy z wybranym profesorem albo w ramach seminarium doktorskiego, czyli też z wolnej stopy, ale we współpracy nie tylko z wybra- 
nym profesorem, ale też $\mathrm{w}$ kontakcie $\mathrm{z}$ innymi doktorantami, a także specjalistami zapraszanymi do współudziału w seminarium. $\mathrm{Z}$ ponadczasowego punktu widzenia te dwie drogi są nawet, paradoksalnie, bardziej uniwersyteckie niż studia doktoranckie, dziejące się w ramach uniwersytetu w obecnym kształcie. Podstawową bowiem formą kształcenia uniwersyteckiego jest osobisty stosunek mistrz - uczeń, włączenie ucznia do przestrzeni badawczej mistrza. Studia doktoranckie ze szkolnymi wymogami mogą przyczyniać się do rozluźnienia tej podstawowej dla uniwersyteckości więzi.

Studia doktoranckie zostały włączone do systemu sformalizowanego kształcenia jako studia trzeciego stopnia, kontynuacja studiów magisterskich. Można powiedzieć, że zostały uznane za właściwą drogę uzyskiwania stopnia naukowego doktora. $Z$ tego względu należy im się przyjrzeć uważnie, nawet gdyby konkluzją miało być uznanie ich za mało przydatne dla funkcji edukacyjnej dziedziny archiwalnej.

Podstawowym aktem prawnym, regulującym funkcjonowanie studiów doktoranckich, jest ustawa „Prawo o szkolnictwie wyższym” z 27 lipca 2005 roku, oczywiście z późniejszymi, bardzo istotnymi zmianami ${ }^{1}$. Ustawa definiuje studia doktoranckie jako „studia trzeciego stopnia [...] prowadzone przez uprawnioną jednostkę organizacyjną uczelni, instytut naukowy Polskiej Akademii Nauk, instytut badawczy lub międzynarodowy instytut naukowy działający na terytorium Rzeczypospolitej Polskiej utworzony na podstawie odrębnych przepisów, na które są przyjmowani kandydaci posiadający kwalifikacje drugiego stopnia, kończące się uzyskaniem kwalifikacji trzeciego stopnia”2. Dalej ustawa określa warunki, jakie musi spełniać jednostka, prowadzące studia doktoranckie: „Jednostki organizacyjne uczelni oraz jednostki naukowe posiadające uprawnienie do nadawania stopnia naukowego doktora habilitowanego albo co najmniej dwa uprawnienia do nadawania stopnia naukowego doktora mogą prowadzić studia doktoranckie w zakresie dyscyplin odpowiadających tym uprawnieniom"3. Ustawa stwierdza obowiązek prowadzenia zajęć dydaktycznych przez doktorantów: „Uczestnicy studiów doktoranckich prowadzonych w uczelni mają także obowiązek odbywania praktyk zawodowych w formie prowadzenia zajęć dydaktycznych lub uczestniczenia w ich prowadzeniu. Maksymalny wymiar zajęć dydaktycz-

\footnotetext{
1 Prawo o szkolnictwie wyższym, DzU 2012, poz. 572 z późn. zm.

2 Tamże, art. 2, ust. 1, pkt 10.

3 Tamże, art. 195, ust. 1.
} 
nych prowadzonych przez doktorantów nie może przekraczać dziewięćdziesięciu godzin rocznie”. I I na koniec ustawa nakłada na ministra obowiązek wydania rozporządzeń: „Minister właściwy do spraw szkolnictwa wyższego określi, w drodze rozporządzenia: 1) reguły kształcenia na studiach doktoranckich, uwzględniając efekty kształcenia i warunki ich uzyskania, 2) zajęcia fakultatywne rozwijające umiejętności dydaktyczne lub zawodowe, minimalny wymiar zajęć oraz liczbę punktów ECTS, 3) wymiar praktyk, w tym realizowanych w formie zajęć dydaktycznych na studiach doktoranckich prowadzonych w uczelni"

Dla rozwiązania problemu, postawionego w tytule artykułu, ważne jest zdefiniowanie profilu kształcenia na studiach doktoranckich. Reguluje te sprawy Rozporządzenie Ministra Nauki i Szkolnictwa Wyższego z 1 września 2011 r. w sprawie kształcenia na studiach doktoranckich w uczelniach i jednostkach naukowych ${ }^{6}$. Mówi się w nim, iż „Studia doktoranckie stwarzają warunki do: 1) prowadzenia samodzielnych badań naukowych [...] 3) przygotowania przez doktoranta publikacji naukowej w formie książki lub co najmniej jednej publikacji naukowej przyjętej do druku w recenzowanym czasopiśmie naukowym o zasięgu co najmniej krajowym lub w recenzowanym sprawozdaniu z międzynarodowej konferencji naukowej lub publicznej prezentacji dzieła artystycznego; 4) realizacji programu studiów, obejmującego zajęcia obowiązkowe, fakultatywne i praktyki zawodowe; 5) przygotowania do egzaminów doktorskich oraz przygotowania rozprawy doktorskiej pod opieką promotora albo promotora i promotora pomocniczego"7.

Rozporządzenie precyzuje wymiar punktowy i godzinowy studiów doktoranckich: „Łączny wymiar zajęć objętych programem całego toku studiów odpowiada od 45 do 60 punktom ECTS, w tym od 20 do 30 punktom ECTS w ramach zajęć fakultatywnych rozwijających umiejętności dydaktyczne lub zawodowe, w wymiarze co najmniej 15 godzin. 2. Fakultatywne zajęcia rozwijające umiejętności dydaktyczne i zawodowe obejmują zajęcia, na których doktorant zdobywa kwalifikację w zakresie nowoczesnych metod i technik prowadzenia zajęć dydaktycznych, w wymiarze odpowiadającym od 10 do 15 punktom ECTS. Zajęcia fakultatywne przygotowują do wykonywania zawodu nauczyciela akademickiego, w szczególności w zakresie metodyki zajęć

4 Tamże, art. 197, ust. 3.

5 Tamże, art. 201, ust. 2.

6 DzU 2011, Nr 196, poz. 1169.

7 Tamże, par. 3. 
dydaktycznych i nowych technologii wykorzystywanych w kształceniu studentów"s.

Znaczy to, że w minimalnym wymiarze żąda się 1080 godzin pracy doktoranta (45 punktów, licząc, że punkt odpowiada od 24 do 30 godzin pracy), w maksymalnym 1800 godzin pracy. Przyjąwszy, że studia trwają cztery lata i doktorant pracuje przez cały czas w równym natężeniu, daje to 8,65 godzin pracy tygodniowo w wariancie maksymalnym. Czy to wystarcza na prowadzenie badań i pisanie prac naukowych, w tym rozprawy doktorskiej? Wyraźnie nie, podane punkty i czas pracy, za nimi się kryjący, muszą odnosić się do samych studiów, a nie do przygotowania pracy doktorskiej. Zastrzeżenia budzi bardzo niska liczba minimalna godzin (15) na zajęcia fakultatywne, a jednocześnie przypisanie im od 10 do 15 punktów, czyli przewidywanie dla nich od 240 do 450 godzin pracy doktoranta. Wynika z tego, że doktorant może podnosić swoje umiejętności dydaktyczne lub zawodowe niemal samodzielnie. Takie samodzielne zdobywanie umiejętności jest o tyle zaskakujące, że połowa tego „samokształcenia” służy przygotowaniu do zawodu nauczyciela akademickiego.

Rozporządzenie mówi ponadto wyraźnie, że „Realizacja programu studiów doktoranckich przygotowuje do pracy o charakterze badawczym lub badawczo-rozwojowym, a w szczególności prowadzi do osiągnięcia efektów kształcenia w zakresie: 1) wiedzy na zaawansowanym poziomie, o charakterze podstawowym dla dziedziny związanej z obszarem prowadzonych badań naukowych, obejmującej najnowsze osiągnięcia nauki lub sztuki oraz o charakterze szczegółowym, odpowiadające obszarowi prowadzonych badań naukowych, obejmującej najnowsze osiągnięcia nauki lub sztuki; 2) umiejętności związanych z metodyką i metodologią prowadzenia badań naukowych; 3) kompetencji społecznych odnoszących się do działalności naukowo-badawczej i społecznej roli uczonego lub artysty" ". Doktorant ma więc obowiązek prowadzenia badań naukowych i przygotowania się do bycia w przyszłości zawodowym uczonym.

Dla profilu kształcenia doktorantów znaczenie ma jeszcze fragment rozporządzenia, mówiący, iż „wymiar praktyk w formie prowadzenia zajęć dydaktycznych dla uczestników studiów doktoranckich prowadzonych w uczelni nie może być mniejszy niż 10 oraz większy niż 90 godzin rocznie”"10.

\footnotetext{
8 Tamże, par. 4.

9 DzU 2011, Nr 196, poz. 1169, par. 5.

10 Tamże, par. 6.
} 
Program studiów doktoranckich w zakresie archiwistyki musiałby zatem obejmować zajęcia z zakresu:

1. archiwistyki (wymiar nieokreślony, ale w tym 10-15 punktów na umiejętności zawodowe);

2. metodologii nauk (wymiar nieokreślony);

3. dydaktyki szkoły wyższej (10-15 punktów);

4. społecznej roli uczonego (wymiar nieokreślony, może to być zawarte w innych przedmiotach);

5. prowadzenie zajęć dydaktycznych, nazywanych praktyką zawodową (40-360 godzin).

Czy z powyższego wynika, że nie jest potrzebne seminarium doktoranckie? Wręcz przeciwnie, to seminarium wydaje się najlepszym miejscem na przekazywanie wiedzy i umiejętności z zakresu metodologii nauk, a także właściwej postawy uczonego, świadomego swej społecznej roli. Seminarium rozumiane nie jako tylko i wyłącznie kuźnia prac doktorskich, ale też miejsce dyskusji z udziałem mistrza, uczniów i zaproszonych gości-ekspertów, powinno być przedmiotem o kluczowym znaczeniu i największym wymiarze godzinowym.

Drugim blokiem przedmiotowym mogłyby być wykłady i konwersatoria z zakresu archiwistyki. Ale i te efekty kształcenia, umiejętnościowe i wiedzowe, osiągnąć można podczas seminarium, które jest najpojemniejszą formą zajęć uniwersyteckich, pozwalających na wykład, konwersatorium, dyskusję i ćwiczenia laboratoryjne.

Problemem pozostają zajęcia mające przygotować uczestnika studiów doktoranckich do funkcji nauczyciela akademickiego. Tej części kształcenia służą zajęcia z zakresu dydaktyki szkoły wyższej i tak zwana praktyka zawodowa, czyli prowadzenie zajęć. Problemem jednak pozostaje charakter tego prowadzenia. W obecnej praktyce uniwersyteckiej, na Uniwersytecie Mikołaja Kopernika w Toruniu, doktorant w ciągu czterech lat musi odbyć 210 godzin zajęć, w tym aż 150 godzin ma poprowadzić samodzielnie. Tylko przez 60 godzin współprowadzi zajęcia, czyli może czegoś się nauczyć od swego mistrza lub bardziej doświadczonych kolegów. Nie ma w ogóle mowy o etapie prowadzenia zajęć przez doktoranta pod okiem mistrza. Nie chodzi o jakieś wizytacje raz w roku. W ogóle odwrócić należałoby kolejność, skoro mowa o praktyce zawodowej. Najpierw dydaktyka szkoły wyższej, potem uczestniczenie w zajęciach mistrza, następnie prowadzenie zajęć pod okiem mistrza, a dopiero na końcu, w wymiarze na przykład 90 lub 60 godzin, samodzielne 
prowadzenie zajęć. Obecnie praktyka zawodowa jest fikcją, a uczelnie szukają w doktorantach darmowej siły roboczej. Doktoranci prowadzący tyle zajęć samodzielnie odpracowują w rzeczywistości koszty przewodu doktorskiego. Jest to tym bardziej opłacalne dla uczelni, że skuteczność studiów doktoranckich jest bardzo niska. Mamy w kraju wielu doktorantów, ale niewielu z nich uzyskuje stopień naukowy doktora.

Wątpliwość budzi kwestia, czy archiwiście potrzebne jest przygotowanie do roli nauczyciela akademickiego? Czy więc potrzebne mu są studia doktoranckie formalne, zgodne z przepisami prawa? Archiwistom stopień naukowy (sic!) potrzebny jest jako potwierdzenie ich umiejętności prowadzenia badań naukowych. Te badania prowadzone mają być, zarówno przed, jak i po uzyskaniu doktoratu, w archiwum i w związku z jego zasobem. Uzyskanie stopnia naukowego doktora jest faktem z zakresu funkcji naukowej dziedziny archiwalnej, a nie jej funkcji edukacyjnej, do której przypisywałyby ten fakt formalne studia doktoranckie.

Zarówno profil uniwersyteckich studiów doktoranckich, jak i obserwacja ich skuteczności wskazuje na nieformalne seminarium doktoranckie jako lepszą formę kształcenia doktorskiego archiwistów. Możliwa jest też forma pośrednia, czyli seminarium obudowane zajęciami, być może $\mathrm{w}$ jakimś zakresie sformalizowanymi, by móc zapłacić nauczycielom. Takie rozbudowane seminarium doktoranckie czy niepełne studia doktoranckie powinny obejmować:

1. seminarium, na którym uczestnicy prezentują wyniki swoich prac,

2. wykłady z zakresu archiwistyki,

3. wykłady $\mathrm{z}$ zakresu metodologii nauk $\mathrm{z}$ uwzględnieniem zastosowań metod $\mathrm{w}$ archiwistyce,

4. ewentualnie wykład $\mathrm{z}$ historii nauki, by uświadomić społeczną rolę uczonego.

Może jednak warto zastanowić się nad krokami, jakie należy podjąć, gdybyśmy uznali za słuszne powołać studia doktoranckie w zakresie archiwistyki? Przede wszystkim archiwistyka najpierw musiałaby stać się uznaną przez ministra dyscypliną naukową. Sprawę tę reguluje Rozporządzenie Ministra Nauki i Szkolnictwa Wyższego z 8 sierpnia 2011 r., które jako załącznik zawiera „Wykaz obszarów wiedzy, dziedzin nauki i sztuki oraz dyscyplin naukowych i artystycznych"11. Archiwistyki nie ma w tym ministerialnym wykazie. Jako że korzenie archiwistyki są historyczne, umieszczamy ją w ob-

11 DzU 2011, Nr 196, poz. 1065. 
szarze nauk humanistycznych, który obejmuje dwie dziedziny: nauk humanistycznych i nauk teologicznych. W dziedzinie humanistycznej jedną z dyscyplin jest historia.

Czy jest szansa i czy warto o to zabiegać, by archiwistyka znalazła się w tym wykazie? Pozwoliłoby to otworzyć studia doktoranckie w zakresie archiwistyki, a także nadawać stopnie naukowe doktora nauk humanistycznych w zakresie archiwistyki, a nie historii, jak dotychczas. Nie jestem przekonany, czy warto tak wąsko się specjalizować, załóżmy jednak, że podejmiemy starania o uznanie przez ministra archiwistyki za odrębną dyscyplinę naukową. Co miałoby ministra przekonać do takiej decyzji? Co świadczy o samodzielności dyscypliny?

Pierwszym wyznacznikiem może być określenie przedmiotu badań i problematyki badawczej z niego wynikającej. Przedmiot archiwistyki to sprawa szybko zbywana w wykładzie uniwersyteckim jako rzecz dość banalna. Archiwa i archiwalia. I starczy. A niesłusznie. Bohdan Ryszewski dał definicję przedmiotu pogłębioną jako relacje między archiwami i archiwaliami ${ }^{12}$. Osobiście widzę archiwistykę jako naukę o dziedzinie archiwalnej. Problematyka badawcza archiwistyki odpowiada tradycyjnie pojmowanym funkcjom archiwów: gromadzeniu, przechowywaniu, opracowywaniu i udostępnianiu archiwaliów. Jak widać, nie można odmówić archiwistyce samoświadomości swego przedmiotu i problematyki.

Drugim wyznacznikiem samodzielności dyscypliny naukowej jest jej metodologia. Nauka jest jednością. Wszystkie jej dyscypliny czerpią z tego samego skarbca metod gromadzenia danych i ich analizy, czyli wnioskowania. Tyle że różne dyscypliny sięgają z różną częstotliwością i w różnych sytuacjach do tych wspólnych metod. Wszystkie dyscypliny posiłkować się mogą tymi samymi modelami badawczymi (supermetodami) albo, tu wykazują często swoją odrębność, wytwarzają własne modele jako precyzyjnie zdefiniowane zespoły metod gromadzenia danych i wnioskowania na ich podstawie, a także procedury stosowania metod niższego szczebla. To właśnie przystosowanie metod ogólnych do potrzeb danej dyscypliny, wskazanie okoliczności, w których dane metody stosować można, warto i należy, nazywamy metodologią danej dyscypliny naukowej. W polskiej archiwistyce takiego przystosowania dokonał Bohdan Ryszewski w swojej przełomowej rozprawie o problemach

12 B. Ryszewski, Archiwistyka. Przedmiot-zakres - podziat (studia nad problemem), Toruń 1972. 
i metodach badawczych archiwistyki ${ }^{13}$. Gdyby było tak, że archiwistyka wykorzystuje całe instrumentarium, przedstawione w tej książce, bez wątpienia praktyka metodologiczna archiwistyki pozwoliłaby uznać ją za w pełni ukształtowaną dyscyplinę naukową. W rzeczywistości jednak naprawdę często wykorzystywany jest tylko model rekonstrukcji procesu archiwotwórczego. Choć opisany językiem informacyjnym, tkwi on genetycznie w naukach historycznych. Wskazane przez Ryszewskiego możliwości wyjścia archiwistyki ku informatologii z trudem przebijają się w praktyce badawczej. Powstają już jednak analizy systemowe np. funkcji edukacyjnej archiwów ${ }^{14}$, czy silnie zmatematyzowane badania efektywności systemu informacyjnego np. Archiwum Państwowego w Toruniu ${ }^{15}$. Choć zdarzają się wciąż błędy wieku dziecięcego archiwistyki, mylenie metod pracy archiwów, np. metody rekonstrukcji zespołu archiwalnego z metodami badawczymi, to jednak trzeba uznać, że archiwistyka ma własną metodologię, upoważniającą ją do aspirowania do uznania jej oficjalnie za samodzielną dyscyplinę naukową.

A jednak czy to wystarcza, by archiwistyka była dyscypliną naukową? Czy przedmiot, problematyka i metodologia to wszystko? Wróćmy do historii. Przeszłość mogą teoretycznie badać i czasem nawet to czynią, choć powinni częściej, politolodzy, socjolodzy, psycholodzy, ekonomiści, antropolodzy. Przecież każda chwila przeszłości to nic innego niż trochę dawniejsza teraźniejszość. Tymczasem politolodzy, socjolodzy, psycholodzy, ekonomiści i antropolodzy zwykle nie opuszczają teraźniejszości, w której żyją. To historycy ogłosili program sięgania po metody socjologii i ekonomii. To historycy stworzyli antropologię historyczną, a nie antropolodzy. To historycy odczuwają niedosyt własnych metod. Czy historia może być li tylko kronikarską opowieścią o wydarzeniach? Nie! A jednak to właśnie konstytuuje historyków, po tym można poznać ich prace mimo sięgania po metodologię innych nauk. Świetna praca Witolda Kuli o miarach i ludziach ${ }^{16}$, w zamierzeniu i dużej mierze naprawdę antropologiczna, dla antropologa jest ostatecznie nie do przeczytania w całości. W końcu bowiem wychodzi z Kuli historyk i książka dla niehistoryka wydaje się przeładowana faktami. Szacunek dla faktu histo-

13 Tenże, Problemy i metody badawcze archiwistyki, Toruń 1985.

14 A. Rosa, Funkcja edukacyjna archiwów, Warszawa 2012.

15 M. Cołbecka, Badanie systemu informacji archiwalnej na przyktadzie Archiwum Państwowego w Toruniu, w tym tomie „Archiwów - Kancelarii - Zbiorów”.

16 W. Kula, Miary i ludzie, Warszawa 2004. 
rycznego, faktu pieczołowicie ustalonego, skrzętnie podanego czytelnikowi, to wyróżnik historyka, spuścizna okresu historii krytycznej, która w każdym prawdziwym historyku tkwi. Nie można przecież myśleć i rozmawiać o przeszłości, nie poznawszy najpierw faktów. Ale właśnie, ostatecznie chodzi o myślenie w oparciu o fakty, a nie o znajomość faktów. Historia krytyczna zostaje dopełniona przez historię procesualną. Historyk dostrzega coś więcej niż jednostkowe fakty. Widzi zjawiska i ich zmienność, czyli procesy historyczne. Teraźniejszość tłumaczy sobie i czytelnikom jako przedłużenie przeszłości. Jest gotów przepowiadać przyszłość. Reprezentuje specyficzną wrażliwość w swoim postrzeganiu świata. Jej istotą jest wyczulenie na zmianę w czasie lub jej brak, zawsze pozorny, skoro obok wszystko się zmienia. A więc czy to specyficzna wrażliwość postrzegania świata jest ostatecznym, najważniejszym wyróżnikiem odrębności dyscypliny? I czy gdy ta osobna wrażliwość zostaje stwierdzona, żadne ministerialne rozporządzenia nie mają już znaczenia?

Czy istnieje i na czym miałaby polegać odrębna wrażliwość archiwistyki? Wrażliwość odpowiadająca wyzwaniom naszych czasów, których wyróżnikiem jest kult różnorodności, a jednocześnie wrażliwość uniwersalna, ponadczasowa. Najpierw o tej ponadczasowości jako zwycięstwie ogólności nad poszczególnością. Jak wciąż odnawia się w dziejach ponadczasowa Respublica Litteraria, ukształtowana w epoce renesansu, rozkwitająca w dobie oświecenia, trochę przygasła w dobie nacjonalistycznego romantyzmu, wciąż jednak obecna w nauce ${ }^{17}$, tak w jej ramach dostrzec można Republikę Archiwistów ludzi, dla których dobrem są archiwalia jako własność całej ludzkości, a nie któregoś z narodów na nią się składających.

Oczywiście, wrażliwość archiwalna to ta, która sytuuje nas w obrębie globalnej Republiki Archiwistów. Globalnej dwojako. Najpierw w sensie obejmowania i równouprawnienia wszystkich ludów Ziemi. Potem w sensie równouprawnienia wszystkich sposobów godziwego wykorzystania archiwaliów. A sposoby tego wykorzystania są obecnie wielorakie, świadczące o naszej człowieczej różnorodności. Pamiętajmy, że archiwalia zawsze ostatecznie mówią o przeszłości, nawet jeśli historycy potrafią na ich podstawie prognozować przyszłość. Historycy są różni, jedni ograniczają się do ustalania faktografii, inni koncentrują się na zmienności w czasie i przestrzeni, jeszcze inni skupiają się na indywidualnym przeżywaniu świata przez poszczególnego człowieka, wszyscy oni jednak poddają dzieje badaniu metodycznemu, zdyscyplinowa-

17 K. Pomian, Europa i jej narody, Warszawa 1992. 
nemu, zgodnemu z pewnymi regułami gry - zabawy. Nikt z nich nie uznaje osiągniętych wyników za ostateczne. Każdy gotów jest wywrócić ustalenia kolegów na nice.

Inni jednak szukają w archiwaliach przekazu, oddającego im sprawiedliwość, wydobywającego ich z zapomnienia, z niebytu, wynagradzającego ich ukrzywdzenie. Częstokroć to oni sami archiwalia im odpowiadające gromadzą jako twórcy archiwów społecznych i prywatnych, albo nawet prowokują ich powstanie przez namowy do tworzenia wspomnień i relacji. Ludzie ci szukają w archiwaliach swojej tożsamości, nie są to uczeni historycy, ale budowniczy pamięci.

Inni jeszcze chcą się przeszłością bawić. Inscenizować wydarzenia historyczne, pisać historie alternatywne, wynajdywać dla swej prywatnej wiedzy informacje o ludziach (często przodkach), miejscach, wydarzeniach.

Może się też zdarzyć, do czego jesteśmy obecnie zachęcani, że archiwalia służyć będą nam - rządzonym do kontrolowania ich - rządzących.

Wrażliwość archiwalna wymaga, by wszystkie te możliwe do pomyślenia sposoby obcowania $\mathrm{z}$ archiwaliami w swoim sercu i umyśle równouprawnić i objąć troską. Tym samym archiwistyka jawi się jako jeszcze jeden sposób spojrzenia w przeszłość, jeszcze jeden rodzaj stosunku do archiwaliów. Wrażliwość archiwalna mówi: postarajmy się, aby każdy w archiwach znalazł to, co jemu jest potrzebne.

To wielkie wyzwanie, zmuszające nas do ciągłego samokształcenia, doskonalenia, poznawania społeczności uczonych i nieuczonych, umiejętności rozmawiania z nimi, odpowiadania na ich oczekiwania Wrażliwość archiwalna sprowadza się do spostrzeżenia, że archiwalia są godne troski jako własność powszechna w najszerszym rozumienia tego słowa. Może to oznaczać chwilami konflikt sumienia archiwisty z oczekiwaniami dysponentów archiwów. Wydaje mi się, że kodeks etyczny archiwistów sugeruje w takich sytuacjach archiwiście archiwalne nieposłuszeństwo władzy ${ }^{18}$.

Wydaje się więc, że archiwistyka dojrzała do bycia odrębną dyscypliną wiedzy. Tym samym można się spodziewać, że w końcu ktoś tę dojrzałość spożytkuje, przez co stworzone zostaną formalne przesłanki do powołania studiów doktoranckich w zakresie archiwistyki. Ktoś na pewno tę szansę wykorzysta wcześniej czy później.

18 Kodeks etyczny archiwisty uchwalony na XIII Międzynarodowym Kongresie Archiwów w Pekinie, „Archiwista Polski” 1997, nr 1, s. 10-14. 


\section{POSTSCRIPTUM}

Wymienić jeszcze wypada formalne wskazania przemawiające za tym, żeby archiwistykę można było uznać za samodzielną dyscyplinę naukową. Są to liczne dysertacje będące podstawą nadawania stopni naukowych doktora z konieczności w dyscyplinie historia, faktycznie będące dysertacjami ściśle archiwistycznymi. Są to coraz częstsze nadawania stopni naukowych doktora habilitowanego ze specjalnością archiwistyka lub nawet archiwistyka i zarządzanie dokumentacją. Od roku 1969 istnieje wreszcie w Polsce instytut w ramach Uniwersytetu Mikołaja Kopernika w Toruniu mający w nazwie odniesienie do archiwistyki.

\section{Bibliografia}

Cołbecka M., Badanie systemu informacji archiwalnej na przyktadzie Archiwum Państwowego w Toruniu, „Archiwa - Kancelarie - Zbiory” 2013, nr 4 (6).

Kula W., Miary i ludzie, Warszawa 2014.

Pomian K., Europa i jej narody, Warszawa 1992.

Rosa A., Funkcja edukacyjna archiwów, Warszawa 2012.

Ryszewski B., Archiwistyka. Przedmiot - zakres - podziat (studia nad problemem), Toruń 1972.

Ryszewski B., Problemy i metody badawcze archiwistyki, Toruń 1985.

\section{Su m mary}

The possibility of establishing a doctoral programme in archive studies

Doctor studies have been included into formalised education system as a third cycle studies. In the light of ministerial regulations, the archive studies doctor programme ought to encompass classes on archives, methodology of sciences, didactics of higher education studies, the social role of an academic, conducting student internship. Does this mean, that a doctoral seminar in archive studies is excessive? On the contrary, the seminar seems to be the best place to bequeath knowledge and skills on methodology and the proper attitude of a scholar, in awareness of his or her role in the society.

By these standards, the seminar should be understood not solely as a place to forge doctoral theses, but also as a site in which to conduct discussion with one's academic authorities and advisors and guest experts, it also should be the key class, tak- 
ing the most of the timetable. The validity of preparing an archivist for the role of a university teacher has been questioned.

Both the profile of the doctor programmes and observation of their effectiveness has led us to believe informal seminar to be the better way of doctoral education for archive students. Perhaps though, the kind of steps, that must be taken if doctor programme on archive studies was to be created, is worth considering. Is there a chance and is it worth striving for the archive studies to be an independent department? It would not only mean opening doctor programmes, but also the right confer a $\mathrm{PhD}$ degree in Humanities, on the subject of archive studies, and not history, as it has hitherto been done. The archive studies have definite research subject, range and methodology. What is noticeable is a kind of archival sensitivity, that allows for all the users and all the purposes for using the resources to be on equal rights. Archive studies have matured, and it is ready to become an independent academic discipline. Thereby, it can be expected, that at last, it's maturity will be put to good use, by allowing formal circumstances to arise for creating an archive studies doctor programme. Someone will certainly take this opportunity sooner or later. 